第 3 表 土猿中からのつる割病菌の検出成績

\begin{tabular}{|c|c|c|c|c|c|c|c|}
\hline & 証 & & 米 & & 残 & 渣 & 土篦 \\
\hline & 事 & & I & & 調盉数 & 病菌数 & $\begin{array}{l}1 \mathrm{~g} \text { 当 } り \\
\text { 藏数 }\end{array}$ \\
\hline 液 & 1) & 液体肥料 & 300 倍 & $280 \mathrm{~m} l$ & 310 & 5 & 15 \\
\hline 肥 & 2) & "I & & $420 \mathrm{~m} l$ & 310 & 3 & 0 \\
\hline 㔔 & 3) & " & 400 倍 & $280 \mathrm{~m} l$ & 325 & 7 & 5 \\
\hline 量 & 4) & 水 & & $300 \mathrm{~m} l$ & 320 & 1 & 0 \\
\hline
\end{tabular}

注：4 区合計

第 4 表 土境浸出液培地上の病菌の生育成䋶

\begin{tabular}{|c|c|c|c|c|}
\hline 液肥施 & 用量 & 事 項 & $\begin{array}{l}\text { 病菌そう } \\
\text { 直徍 }(\mathrm{cm}) \\
\end{array}$ & $\mathrm{pH}$ \\
\hline 1) & 液体肥料 300 培 & $280 \mathrm{~m} l$ & 2.7 & 6.43 \\
\hline 2) & "I & $420 \mathrm{~m} l$ & 2.7 & 6.10 \\
\hline 3) & 400 傍 & $280 \mathrm{~m} l$ & 2.7 & 5.89 \\
\hline 4) & 水 & $300 \mathrm{~m} l$ & 2.8 & 6.93 \\
\hline
\end{tabular}

生育には差がなくこの浸出液のpHは液体肥料区がわず かに無施用区よりも低い傾向があったが，病菌の生育・ 発病に影響したとは思われなかった。

2 ) 液体肥料稀瀵培地による培養試験

病菌の生育に対する夜体肥料の直接的影響を調查する ため，500倍，1，000倍，2,000倍稀橎液ならびに各稀粎 淮 $300 \mathrm{~m} l$ に土壤 $300 \mathrm{~g}$ を 3 角フラスコに入れて振とうした 上澄み液およびこの土壤混合液を 10 日間放置した後の上 澄み液の各娌理区を設け，これらの液 $10 \mathrm{~m} l$ に寒天 $0.2 \mathrm{~g}$ を加元て高圧殺菌し，発病試験 1 ）と同様の方法でつる 制病菌を培養し，病菌の生育を調查した。結果を第 5 表 に示したが，液体肥料の各濃度わよび好理を行なった培

第 5 表 液肥培地上における病菌の生甪成績

\begin{tabular}{|c|c|c|c|c|}
\hline \multirow{2}{*}{\multicolumn{2}{|c|}{ 液肥澧度 }} & \multicolumn{3}{|c|}{ 病菌そう直经 (cm) } \\
\hline & & 液 肥 & $\begin{array}{l}\text { 液肥, 土 } \\
\text { 壤混合 }\end{array}$ & $\begin{array}{l}\text { 同 左 } \\
10 \text { 間 }\end{array}$ \\
\hline 1) 液体肥料 & 500倍 & 4.5 & 4.3 & 4.2 \\
\hline 2) & 1,000 倍 & 4.1 & 4.3 & 4.1 \\
\hline 3) & 2,000 倍 & 4.3 & 4.7 & 4.3 \\
\hline 4) & & 4.4 & 4.3 & 4.2 \\
\hline $\mathrm{F}$-检 & 定 & n. s. & n.s. & n.s. \\
\hline
\end{tabular}

地間で病菌の生育に差を認めなかった。

\section{3. キュゥリ生育状況調查}

1) 径 $30 \mathrm{~cm}$ 鉢における調査

発病試験 1) の佳 $30 \mathrm{~cm}$ 鉢のキュウリについて 6 月 1 日 は種数当りの草丈を調查した結果は，各処理区間に差は ないように思われた(第 6 表)。

2）殺菌土壤に㧍ける調查

液体肥料の施用が根に謴度障害をおこして発病を容易 にするものか検討するため，土壤を殺菌して陚験を行な つた。10月14日，発病試験 1）に使用した径 $30 \mathrm{~cm}$ 鉢の土 壤 $400 \mathrm{~g}$ を经 $7.5 \mathrm{~cm}$ ，長さ $15 \mathrm{~cm}$ の゙ラスコップにつめ，温 湯 $75^{\circ} \mathrm{C} の$ 中に 1 時間入れて殺菌した。後品種久留米落合 H型を 8 粒あては種して, 草丈を14日後, 根の褐変を 37 日後に外観上調查した。

第 6 表 キュウリの生育調查成績

\begin{tabular}{|c|c|c|c|c|c|c|}
\hline$==-2+1$ & $+\cdots$ & 土 & 病土 & 殺 & 菌 & 士 境 \\
\hline 液肥施用量 & & & $\begin{array}{l}\text { 菶丈 } \\
\text { (cm) }\end{array}$ & $\begin{array}{l}\text { 草文 } \\
\text { (cm) }\end{array}$ & $\begin{array}{l}\text { 根長 } \\
\text { (cm) }\end{array}$ & $\begin{array}{l}\text { 維根 } \\
\text { 褐变程度 }\end{array}$ \\
\hline 1）液体肥料 & 300 倍 & $280 \mathrm{ml}$ & 38.1 & 3.1 & 7.1 & $\pm \sim 1$ \\
\hline 2) & & $420 \mathrm{~m} l$ & 40.0 & 3.3 & 7.3 & ـــ \\
\hline 3) & 200 倍 & $280 \mathrm{~m} l$ & 33.7 & 3.2 & 8.5 & $\pm \sim+$ \\
\hline 4) & & $300 \mathrm{ml}$ & 34.8 & 5.2 & 11.5 & - 工 \\
\hline F & 検 & 定 & n.s. & n. s. & n. s. & \\
\hline
\end{tabular}

注：a）生育調査は播種 1 粒当りの生育を示す

b）一褐変なし，士不明確，上わずかに褐変あり， 十褐変あり

結果は第 6 表のとおりで，草丈，根長は液体肥料区で は発考不揄いになり，やや短いように思われたが有意差 はなかった。根の褐変も差があるとは思われなかった。

要 約

キュウリつる割病の発病は液体肥料の多用により無施 用上りも多くなる傾向があった。その要因として液体肥 料による病菌の繁殖促進，あるいは根に対する濃度障㕩 の点から検討を行なったが明らかでなかった。

\section{参考文 献}

1）河合一郎・鈴木春夫 $(1956)$ ：農業及園芸，31，831835 2) 下長根鴻・松田 明 - 平野喜代人(1967)：日植 病報 (講要)，33，89-90

\title{
白菜体上における白菜軟腐病菌の移動に関与する水の役割
}

$$
\text { 小林研 三(熊本県農業試験場) }
$$

白葉体上における白菜軟窝病菌 (Erwinia aroideae) 動についてはすでに1961年に報告したが，移動の条件・
要因についてはいまだ解決されていない閃題が残ってい る。最近，烟地かんがいが各地で行なわれているが， 
葉菜類では軟简病の発病が多いといわれている。そこで この多発の現象を解明する一助として，ある湿度条件下 に扔ける白菜体上の水分と軟窝病菌の動静との関係につ いて検討した。

\section{実 験 方 法}

場所は熊本市上の郷时, 県農試病虫部実験室内におい て1969〜70年に実施した。

（1）供試作物 ハクサイ(品種杤緑)，播種日 6 月11 日，殺菌砂土上に播種，春日井氏畑培盖液を灌注し，播種 後 2 週間経過したものを供試した。生育期は 3 葉, 4 葉時 の炏苗で, 育苗チューブは口径 $1.8 \mathrm{~cm}$ 高さ3.6cmのガラス 製，供試に先だって土壤水分 $100 \%$ になるように殺菌水 を充分灌水し，一昼夜わいて所定湿度のデシケーター内 に入れた。湿度は $\mathrm{K}_{2} \mathrm{SO}_{4}(98 \%), \mathrm{Na}_{2} \mathrm{CO}_{3}(88 \%), \mathrm{NaCl}$ $(76 \%), \mathrm{NH}_{4} \mathrm{NO}_{3}(64 \%), \mathrm{CaCl}_{2}(32 \%)$ の各飽和復を小

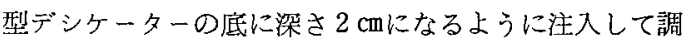
整した(第 1 図)。デシケーター内には各試料 2 個宛入れ て, 陽光定温器 $25^{\circ} \mathrm{C}$ に設置, 3 回反復实験になるように し, 処理别, 湿度別に分汁た。

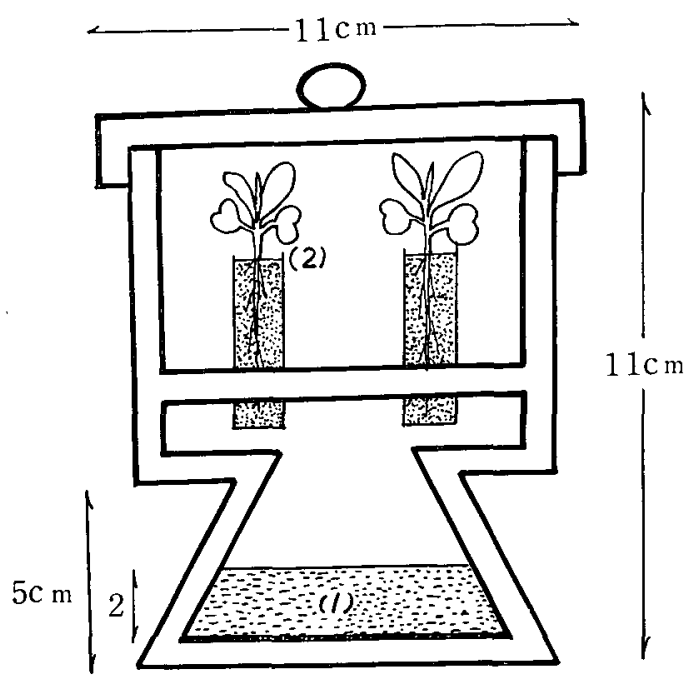

第 1 図各湿度別の実験装置

(1) 湿度, 調節溶液

（2）供陚植物体

（2）接種方法 接種菌は熊本市，県農試ほ場で採集 (E. aroideae ) した農試保存菌 $\left(25^{\circ} \mathrm{C}\right)$ で菌液濃度は 1 $\times 10^{4} / \mathrm{m} l$ で 2 白金耳を植物体上の接種点に叙沫接種し た。まえもって供試菌の病原性を見るため纤植物に対し て針接種を行ない，48時間後発病の有無を調査した。

（3）試験区の内容 I . 散水した直後接種 1 ）根 部全面接種（根部 $1 ２$ ） 区，2）根部上部（根部 2 ） 接種区，3）対照無処理。II. 接種時の水の有無 1)

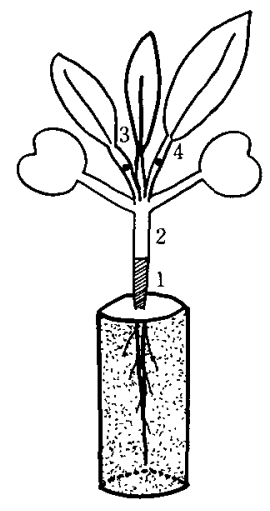

第 2 図 供試植物体の接種, 検定部位

有水区，2）無水区 接種は根部下部（根部1）に行な った。

植物体の接種部位は第 2 図のとおりである。

（4）調查項目わ上び細菌移動の確認方法 接種発病 調查は幼苗について $2 \sim 4$ 回反復し実施した。接種後 48 時䦭経過後発病調查をした。

また細菌の接種点よりの移動の有梨を調査するため接 種 24 時間後所定検定部位(第 2 四)の菌の澧度の大略を測 定した。方法は検定部位組織を各々 $1 \sim 2 \mathrm{~mm}$ の切片とし て採集し,殺菌試験管内で軽く磨砕し，その中にあらかじ め溶かした馬鈴薯寒天培地を注入し常法により菌数の測 定を行なった。表示は菌の移動をみる目的であるため概 数をとり, $0=$ 琹めず $0.5=<1 \times 10^{3}, 1=10^{3}, 2=1 \times 10^{4}$ とした。

\section{実 験 結 果}

1. 幼植物にお汀る発病調查

病原性の有無を確めた後、病原性のある菌を供試した が幼植物接種の場合，第 1 表，第 2 表のとおり割合に発 病少なく，湿度別では，菌の濃度か低かったが一応湿度 が高くなるほぞ発病が多いようであった。

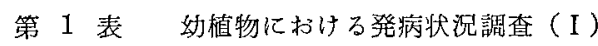
湿度別

\begin{tabular}{c|c|c|c|c|c}
\hline 湿度 & $98 \%$ & $88 \%$ & $76 \%$ & $64 \%$ & $32 \%$ \\
\hline 発病茎率 & $3 / 6 \cdot$ & $0 / 6$ & $0 / 6$ & $2 / 6$ & $0 / 6$ \\
\hline
\end{tabular}

第 2 表 幼植物における発病状況調查（II） $25^{\circ} \mathrm{C}$

\begin{tabular}{c|c|c|c|c}
\hline \hline 反 復 & 1 & 2 & 3 & 4 \\
\hline 発病桑率 & $1 / 10$ & $0 / 10$ & $0 / 10$ & $0 / 10$ \\
\hline
\end{tabular}

2. 植物体上にお汀る細菌の移動状況

細菌の移動恔接種点以外にも想められ，条件の違いで 
第 3 表 植物体上における細菌の移動と湿度との関係

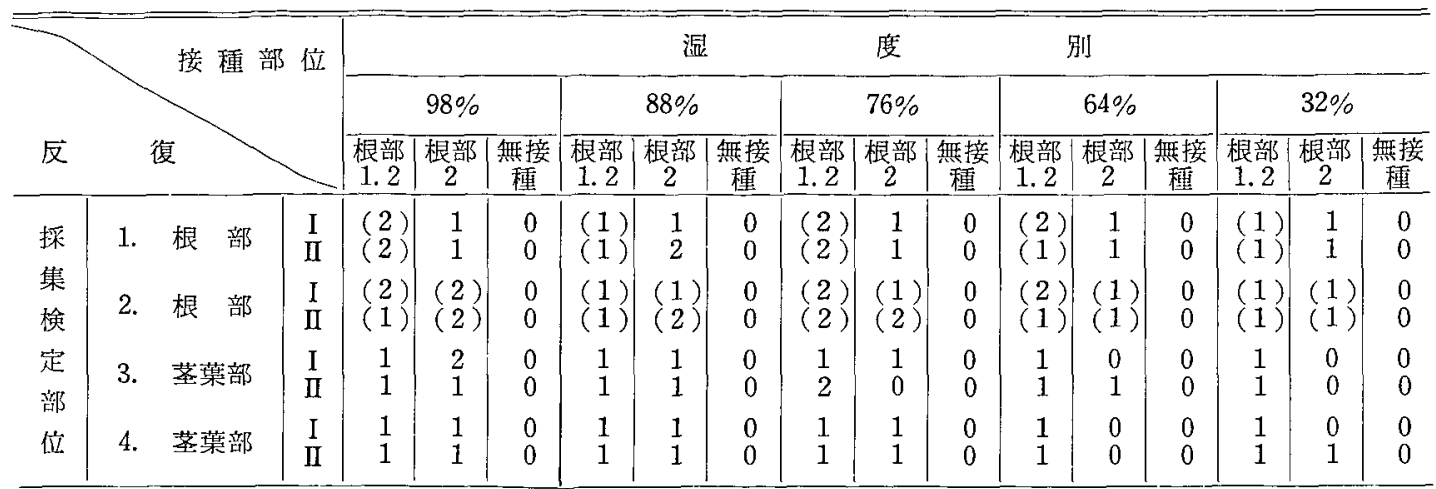

注：細菌数 0 : 認めす $0.5:<1 \times 10^{3} \quad 1: 1 \times 10^{3} \quad 2: 1 \times 10^{4}$

（）は菌の接種点を示す。

第 4 表 植物体上における細菌の移動と水分の有無との関䋆

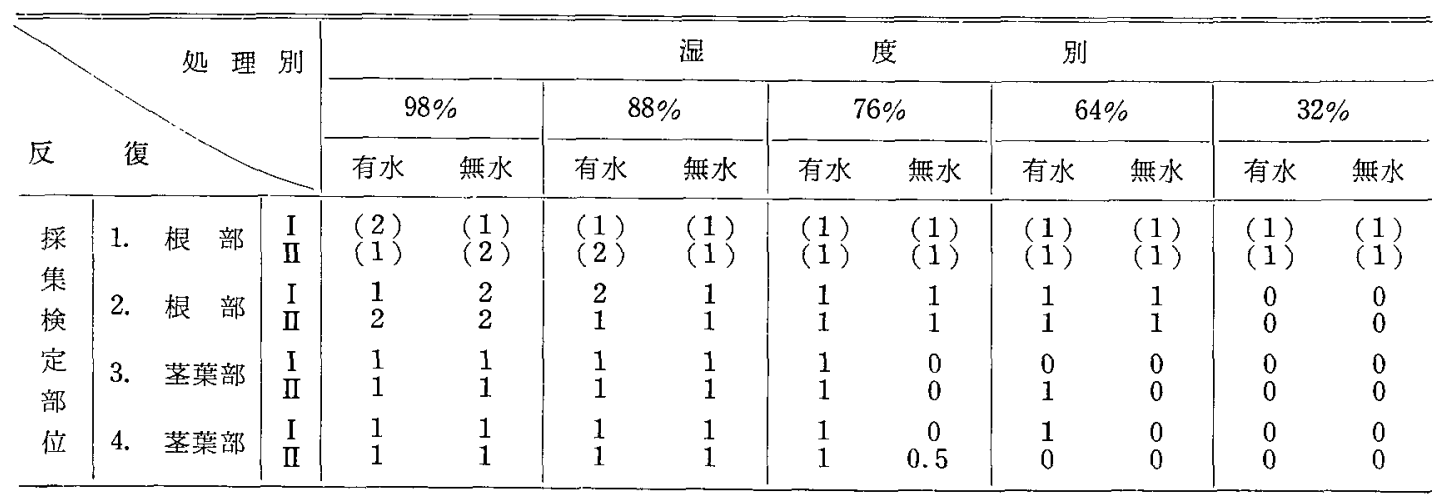

注 細菌数 0 : 認めず $0.5:<1 \times 10^{3} \quad 1: 1 \times 10^{3} \quad 2: 1 \times 10^{4}$

（）は接種点を示す

第 5 表 水分, 湿度条件汇上る細菌の移動 状沅取りまとめ(第 3 , 第 4 表)

\begin{tabular}{l|c|c|ccccc}
\hline 水分有無 & 湿度 $\%$ & 98 & 88 & 76 & 64 & 32 \\
\hline & 根部(2) & 有 & $6 / 6$ & $6 / 6$ & $5 / 6$ & $3 / 6$ & $3 / 6$ \\
\hline $\begin{array}{l}\text { 接 } \\
\text { 部 }\end{array}$ & 根部(1) & 有 & $6 / 6$ & $6 / 6$ & $6 / 6$ & $4 / 6$ & $0 / 6$ \\
\hline 柆 & 根部(1) & 無 & $6 / 6$ & $6 / 6$ & $2 / 6$ & $2 / 6$ & $0 / 6$ \\
\hline & & $18 / 18$ & $18 / 18$ & $13 / 18$ & $9 / 18$ & $3 / 18$ \\
\hline
\end{tabular}

注：表中数字は 分母: 接種点を除いた総検体数, 分 子：細菌を恋めた検体数。第 3 表については根部 2 区のみ。

幾分差違は認められるが，明らかに植物体上の細菌の移 㖵は行なわれるようである。

\section{考察ならびに結論}

白菜体上の軟旡病菌の動静についてはすでに筆者は概
論的に報告したが詳細には（特に条件，要因）明らかに していない点があった。また津山もタバコ空洞涡菌がタ バコ茎上を移動することを報告している。しかし移動条 件, 要因については過去の研究では未詳の点が残されて いた。C. Leben は健全植物の表面で増殖する細菌は水 が絶えず存在するとき多く、キュウり種子から笛の表面 への細菌の移動は関係湿度 $90 \%$ 以上のとき大きいとし た。

本実験を行なった結果, 軟简病菌の第 1 次伝染に関与 する環境因子としては特に菜体上の水分と湿度が高い とき本菌の移動は確かに行なわれることが決論的には立 証されたといえよう。幼苗時に接種した場合の本病の発 病は少ない上うで98\%の湿度のとき僅かに発生を認めた に過ぎない。細菌の接種点よりの移動について根部より 葉柄に移唾するものは散水した後に接種を行なった場合 多いようで，水分が植物体上の細菌の移動に関係してい る。植物体上に水分がなくても細菌の移動は見られるが あまり活発とはいえない。水分が介在すれば湿度の大小 
に余り関係なく，98～76\%の湿度の場合と64～32\%の場 合とでは差異が涩められる程度であった。植物体上に水 分がない場合は，細菌の移動に及ぼす湿度の影樂は大き く, 98〜88\%の高湿度では64〜32\%の低湿度のときより 活発であった。

本実験の結果では水分の有與条件により移動の㫰否が あって葉上の水分の存在は細菌移動条件要因の一つであ るように考える。白菜集上の紐菌の分散は種々の方法で 行なわれるが，この上うに発病以前に菌の增殖，分散が 行なわれることは菌の侵入待機姿埶として極めて貫要な 現象といえよう。

烟地灌溉，降雨などの白菜葉上の水分によりこの現象
が行なれれると想像される。葉上に水分をもつ機会が多 ければ多いほど移動・分散が行なわれるであろう。莝部 下部の株元より土砂が飛散，付着し，それを基点として 水を介して移動, 流下するなど種々の方法, 様相が明ら かに想像される。分散された菌は葉上で増殖しながら傷 夷形成をまって侵入，発病すると考えられる。しかし植 物体上の細菌の移動機構の微細な解明が必要で機会があ れば今後充分究明したいと考えるが，畑灌など高温高湿 の罟境条件が急に造られる場合には本央験の結果が本病 多発の要因究明の病理学的考察の一証左となりうると考 えら扎る。

\section{ナンキンマメさび病の発生について

\begin{tabular}{|c|c|c|}
\hline 須 & 利 & 則（長崎県総合農林試験場） \\
\hline 川 & 政 & 罗（五島病害虫防除所） \\
\hline
\end{tabular}

従来,ナンキンマメの葉を侵す主要な病害として, 黒 啮病, 褐环病などがあげられ，一般にこれらを対象に防 除対策がとられてきた。ところが1970年，長崎県下の+ ンキンマメ载培地带のほとんど全域に，さび病が大発生 し，とくに下五島の一部では，激発のため相当の被書を 受けた。

ナンキンマメのさび病については,わが国では記載が なく，沫知の病慧であり，また，1970年の被害の状沅か らみて, 今後, わが国のナンキンマメ栽培に, かなりの 打撃を与える病邫となる恐扎もあるので，その発生につ いて報告しておきたい。

なお，平塚直秀博士には病原菌の同定をしていただ き，貴重な助言を賜わった。さらに，本場作物部烟作 科，鶴内孝之科長，福江農業改良普及所の各位には，調 査に当って多大の御協力をいただいた。愿くお礼を电し 上げる。

\section{発生 状況}

本病は1969年に，南忪浦郡岥宿町で数株に発生を確認 しており，同郡三抖楽町でも軽度の発生をみたとの情報 があった。すなわちこの年の発生はきわめて䡕く，局部 的であった。ところが1970年には，8月下旬に福江市で 初発して以来, 9 月上旬から中旬にかけて, 福江市の全 域のみならず，岐宿町，三井楽町，富江町，玉ノ浦町な ど下五島の全域, 諫早市, 大村市, 佐世保市, 平戸市, 島原半島の各地など，県下のナンキンマメ栽培地带のほ とんど全培に発生するに至った。

とくに下五島での発生がはなはだしく，9月下旬に は，本病によって全株枯死したほ場が各地にみられた。

その他の地域でも，10月上旬にはかなりの多発生となっ た。

1970年の県下のナンキンマメ栽培面積は約 378 haであ るが，およそ，その90\%に当る340haにさび病が発生し たものと推定している。とくに発生のはなはだしかった 下五島では，発生程度「多」および「甚」に該当する面 積が，栽培面積の約70\%に当たる39haを占めた。本病の 発生時期, 発生程度からみて, ナンキンマメの収量, 品 貿に対する影響はかなり大きかったものと思われる。

\section{品種（系統）ならびに载培法と発病}

これらの問題については，本病の防除対策上重要であ るので，今後詳細に検討しなければならないが，1970年

第 1 表 踓病程度の品種（系統）間差

(10月13日調査)

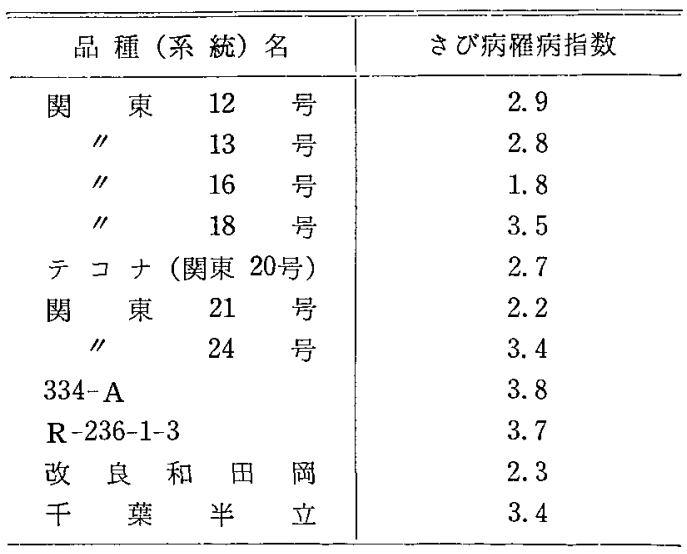

注: 20 株の平均椎病指数 2 区制 